\title{
IDENTIFIKASI MORFOLOGI dan PARAMETER SPESIFIK SIMPLISIA DAN EKSTRAK DAUN ROSELLA (Hibiscus sabdariffa L.) ASAL KAB. ENREKANG (SULAWESI SELATAN)
}

\author{
A.Amalia Dahlia, Asni Amin, Rahayu Lestari \\ Fakultas Farmasi Universitas Muslim Indonesia \\ Email : dahliaamalia@yahoo.co.id
}

\begin{abstract}
Identification of morphology and spesific parameters from simplicia and rosella leaf's extract (Hibiscus sabdariffa L.). From regency of Enrekang, South Sulawesi. Identification of morphology and spesific parameters from simplicia and rosella leaf's extract have been done. The aim of this research is to know morphology and to get data of spesific parameters from simplicia and rosella leaf's extract (Hibiscus sabdariffa L.). Morphology test showed that rosella leaf's had spesific characteristic, i.e had red nervatio, had three palmatifidus leaf and their edge of leaf was serrated. Microscopic test of simplicia showed that the shape of their xilem was spiral and ladder, mesophyl, had thick trachoma, Ca.oksalat shaped sand, fibers sklerenkim, oil cells, epidermis and, diasitik stomata type, cortical parenchyma and lymph lysogen. Chemical identification of rosella leaf's powder showed that lignin, cathecol, aleuron, and flavanoid. Spesific parameters of extract showed that water soluble compound was $6,6203 \%$ and ethanol soluble acompund was 18,6992\%. Identification of chemical group used Thin Layer Chromatography that sprayed by spesific reagent showed that the extract contained terpenoid and flavonoid.
\end{abstract}

Key word : Identification, morphology, Hibiscus sabdariffa $L$

\section{PENDAHULUAN}

Indonesia berada di daerah

tropis. Banyak keanekaragaman tanaman yang ada di Indonesia. Berbagai macam tanaman dapat dimanfaatkan sebagai bahan pangan maupun obat. Salah satu tanaman yang dapat dijadikan bahan obat dan dihidangkan yaitu tanaman rosella dalam bahasa latin Hibiscus sabdariffa L. (Hidayat, 2007). Rosella mempunyai kemiripan dengan Kembang sepatu karena memang tanaman ini masih satu famili yaitu Malvaceae. Di Indonesia, belum banyak masyarakat yang memanfaatkan tanaman Rosella. Sementara di negara lain, Rosella sudah banyak dimanfaatkan sejak lama. Sebenarnya seluruh bagian tanaman, mulai buah, kelopak bunga, mahkota bunga, dan daunnya dapat dimakan (Mardiah, 2010). 
Rosella mempunyai lebih dari 100 varietas tersebar di seluruh dunia. Dari sekian banyak verietas rosella yang paling terkenal adalah Hibiscus sabdariffa dan H.altissima webster (Hidayat, 2007). H.altissima webster biasanya dimanfaatkan untuk diambil serat batangnya. Rosella tipe ini tumbuh tegak, tidak banyak bercabang, dengan tinggi mencapai 4,8 m. Batangnya berwarna kuning dengan kelopak berwarna hijau dan merah, tidak berdaging, berduri dan tidak biasa dimakan. Rosella jenis ini batangnya mengandung serat lebih tinggi sehingga biasa digunakan untuk membuat karung (Mardiah, 2010).

\section{Sedangkan}

Hibiscus

sabdariffa memiliki sosok lebih pendek, bentuk semak. Mahkota rosella berwarna merah sampai kuning dengan warna kuning lebih gelap dibagian tengahnya, corong terdiri dari lima helaian (Mardiah, 2010).

Nama Hibiscus berbeda di setiap Negara. Di Australia tanaman ini dikenal sebagai Rosella. Di India, Rosella dikenal dengan nama Meshta atau Chinbaung. Di Myanmar, Rosella dikenal dengan nama Krajeb. Di Thailand dikenal dengan nama Bissap. Di Malaysia, Rosella dikenal dengan nama Asam paya atau Asam susur. Di Indonesia dikenal denggan sebagai
Rosella, Asam paya, Asam susur dan Frambozen. Di Kepulauan Karibia dan Jamaika Rosella dikenal sebagai Sorrel. Di Namibia dikenal sebagai Omutete. Di Mesir, Sudan, dan Arab Saudi, Rosella dikenal dengan nama Karkade, Di Prancis, Rosella dikenal sebagai Oseille sedangkan di Cina Rosella dikenal sebagai Luo shen hua (Mardiah, 2010).

Sebagian masyarakat Makassar menganggap tumbuhan ini tumbuhan liar yang tidak mempunyai khasiat dan hanya sebagian kecil masyarakat Makassar yang telah memanfaatkan daun dari Rosella ini sebagai diuretik (peluru air seni) berdasarkan empirik dan masyarakat Enrekang menggunakannya sebagai obat rhematik.

\section{METODE PENELITIAN}

\section{A. Alat dan Bahan,}

Alat dan bahan yang akan digunakan disiapkan sesuai dengan kebutuhan penelitian.

\section{B. Prosedur Kerja}

\section{Pemeriksaan morfologi daun}

Pemeriksaan morfologi dilakukan dengan mengamati bentuk fisik dari daun Rosella, meliputi bentuk daun, dan sifatsifat daun serta rumus tata letak daun pada batang (filotaksis), dan dilengkapi dengan foto 
daun saat dilakukan pengamatan.

2. Reaksi identifikasi kimia serbuk daun Rosella

a. Reaksi identifikasi terhadap lignin

Serbuk dibasahi dengan larutan fluroglusin LP, ditambah $\mathrm{HCl} P$, diamati dibawah mikroskop, dinding sel yang berlignin akan berwarna merah.

b. Reaksi identifikasi terhadap tannin

a) Reaksi identifikasi terhadap katekol

1) Serbuk ditambah dengan larutan $\mathrm{FeCl}_{3}$ $1 \mathrm{~N}$, jika mengandung katekol, akan menghasilkan warna hijau.

2) Serbuk ditambah dengan larutan brom, jika mengandung katekol, akan terjadi endapan.

b) Reaksi identifikasi terhadap pirogalotanin

1) Serbuk ditambah dengan larutan $\mathrm{FeCl}_{3}$ $1 \mathrm{~N}$, jika mengandung pirogalotanin, akan menghasilkan warna biru.

2) Serbuk ditambah dengan larutan brom, jika mengandung pirogalotanin, tidak terjadi endapan.

3) Serbuk ditambahkan $\mathrm{NaOH} \quad$ jika menghasilkan warna merah coklat, berarti mengandung pirogalotanin.

c) Reaksi identifikasi terhadap dioksiantrakinon

Serbuk dimasukkan ke dalam tabung reaksi, lalu ditetesi dengan $\mathrm{KOH}$ $10 \% \mathrm{~b} / \mathrm{v}$ dalam etanol 90\% $\mathrm{P}$, jika mengandung dioksiantrakinon akan menghasilkan warna merah.

d) Reaksi identifikasi terhadap fenol

1) Serbuk dimasukkan dalam vial, ditambahkan air, lalu ditutup dengan kaca objek, yang diatasnya telah diberi kapas 


$$
\begin{aligned}
& \text { yang telah dibasahi } \\
& \text { dengan air, kemudian } \\
& \text { dipanaskan. Setelah } \\
& \text { ada uap yang berupa } \\
& \text { cairan pada kaca } \\
& \text { objek, diambil dan } \\
& \text { ditambahkan } \mathrm{FeCl}_{3} \mathrm{P} \text {, } \\
& \text { jika mengandung } \\
& \text { fenol akan } \\
& \text { menghasilkan warna } \\
& \text { biru hitam. }
\end{aligned}
$$

\section{e) Reaksi identifikasi terhadap alkaloid}

Dimasukkan

ekstrak etanol daun rosela ke dalam masingmasing tabung reaksi, kemudian ditetesi :

1) $\mathrm{HCl} 0,5 \mathrm{~N}$ dan pereaksi mayer, jika mengandung alkaloid maka akan menghasilkan endapan putih.
2) $\mathrm{HCl} 0,5 \mathrm{~N}$ dan pereaksi bauchardat, jika mengandung alkaloid maka akan menghasilkan endapan coklat.

3) $\mathrm{HCl} \quad 0,5 \mathrm{~N}$ dan pereaksi dragendroff, jika mengandung alkaloid maka akan menghasilkan endapan berwarna jingga.

f) Reaksi identifikasi terhadap karbohidrat

$$
\begin{aligned}
& \text { Serbuk dikocok } \\
& \text { dalam air, lalu } \\
& \text { dimasukkan dalam } \\
& \text { tabung reaksi kemudian } \\
& \text { ditetesi : }
\end{aligned}
$$


menghasilkan

endapan

kuning

jingga.

\section{g) Reaksi identifikasi \\ terhadap pati dan aleuron}

1) Serbuk di tempatkan di atas kaca objek, kemudian ditetesi dengan larutan iodine $0,1 \quad$ N. Jika mengandung pati akan berwarna biru, dan warna kuning coklat sampai coklat jika mengandung aleuron.

2) Serbuk dimasukkan ke dalam tabung reaksi lalu ditetesi dengan pereaksi luff dan dipanaskan. Jika mengandung pati akan menghasilkan endapan merah bata.

h) Reaksi identifikasi terhadap steroid

Ekstrak eter

dimasukkan dalam tabung reaksi kemudian ditetesi pereaksi Liberman Burchardat. Jika mengandung steroid

akan berwarna biru sampai hijau.

i) Reaksi identifikasi terhadap saponin

Serbuk dimasukkan dalam tabung reaksi, tambahkan $10 \mathrm{ml}$ air panas, dinginkan kemudian kocok kuatkuat selama 10 detik, terbentuk buih, lalu ditambahkan 1 tetes asam klorida $2 \mathrm{~N}$, buih tidak hilang.

j) Reaksi identifikasi terhadap flavanoid

Sampel dimasukkan dalam tabung reaksi lalu ditambahkan $\mathrm{FeCl}_{3}$ lalu ditambahkan $\mathrm{HCl}$. Jika terbentuk warna merah keunguan berarti menunjukan adanya flavanoid.

3. Penetapan parameter spesifik

a. Parameter identitas ekstrak

Parameter identitas ekstrak dilakukan dengan memberikan identitas objektif dari nama tumbuhan. Deskripsi tata nama mencakup nama ekstrak, nama latin 
tumbuhan, bagian tumbuhan yang digunakan, serta nama Indonesia tumbuhan.

b. Uji organoleptik

Uji organoleptik merupakan pengenalan awal yang sederhana sesubjektif mungkin. Uji organoleptik dilakukan dengan pengamatan terhadap bentuk, warna, bau dan rasa.

c. Uji senyawa terlarut dalam pelarut tertentu

1. Kadar senyawa yang larut dalam air

a) Pembuatan kloroform LP

Air kloroform LP dibuat dengan mengocok $2,5 \mathrm{ml}$ kloroform $\mathrm{P}$ dengan $900 \mathrm{ml}$ air sampai larut dan diencerkan dengan air hingga $1000 \mathrm{ml}$.

b) Uji kadar senyawa yang larut dalam air

\begin{tabular}{lr}
\multicolumn{2}{c}{ Sebanyak } \\
gram & serbuk \\
simplisia & dimaserasi \\
dengan & $100 \mathrm{ml}$ air \\
kloroform LP selama \\
24 jam dengan
\end{tabular}

menggunakan labu bersumbat sambil berkali-kali dikocok selama 6 jam pertama dan kemudian dibiarkan selama 18 jam. Disaring, uapkan 20 $\mathrm{ml}$ filtrat hingga kering dalam cawan dangkal berdasar rata yang telah ditara, panaskan sisanya pada suhu $105^{\circ} \mathrm{C}$ hingga bobot tetap. Hitung kadar persen sari yang larut dalam air, dihitung terhadap ekstrak awal.

2. Kadar senyawa yang larut dalam etanol (95\%)

Sebanyak 5 gram serbuk simplisia dimaserasi dengan 100 $\mathrm{ml}$ etanol (95\%) selama 24 jam menggunakan labu sumbat sambil berkali-kali dikocok selama 6 jam pertama kemudian dibiarkan selama 18 jam. Disaring, uapkan $20 \mathrm{ml}$ filtrat 


hingga kering dalam
cawan dangkal berdasar
rata yang telah ditara,
panaskan sisa pada
suhu $105^{\circ}$ hingga bobot
tetap. Hitung kadar
persen sari yang larut
dalam etanol (95\%),
dihitung terhadap
ekstrak awal.

d. Uji kandungan kimia ekstrak

\section{Ekstraksi \\ secara \\ Maserasi \\ dengan \\ Pelarut Etanol}

a. Daun

Rosela

(Hibiscus sabdariffa

L.) sebanyak 200 gram kemudian dimasukkan

kedalam

wadah

maserasi,

lalu

ditambahkan etanol

sebanyak $2000 \mathrm{ml}$

hingga merendam

seluruh simplisia,

dan dibiarkan

selama 3 hari dalam

bejana tertutup dan

terlindung dari

cahaya disertai

dengan pengadukan

setiap hari. Setelah

3 hari ekstrak disaring dalam

wadah penampung,

kemudiaan

ampasnya direndam

lagi dengan cairan

penyari baru,

penyarian dilakukan

sebanyak tiga kali.

Ekstrak yang

diperoleh diuapkan

dengan bantuan

kipas angin hingga

kental dan difrezz

dryer sehingga

diperoleh ekstrak

kering.

b. Profil KLT ekstrak

Sebanyak $5 g$ difraksinasi berturutturut dengan pelarut n-heksan, etil asetat, dan air. Masingmasing $10 \mathrm{ml}$ setiap perlakuan.

Fraksinasi dilakukan dengan pengocokan selama 15 menit :

a) Uji terpenoid

Fase gerak dicampur heksan-etil asetat

dimasukan ke dalam chamber dan dibiarkan sampai 
jenuh. Pada plat KLT

$\mathrm{GF}_{254}$ ditotol sari

heksan dan

dimasukkan dalam

chamber, dielusi

sampai tanda, diambil

dan dibiarkan sampai

kering. Ekstrak

mengandung

terpenoid bebas bila

dilihat dibawah sinar

UV $356 \quad \mathrm{~nm}$

berflourosensi

hijau/berwarna merah

ungu.

b) Uji alkaloid

Dibuat fase gerak etil asetat-metanol-air (10:2:1) dimasukan dalam chamber, dibiarkan sampai jenuh. Pada plat KLT

$\mathrm{GF}_{254 p}$ ditotolkan sari

etil asetat dan

dimasukan dalam

chamber, dielusi

sampai tanda, diambil dan dibiarkan sampai

kering. Ekstrak

mengandung

terpenoid bebas bila

dilihat dibawah sinar

UV $356 \quad \mathrm{~nm}$

berfluoresensi hijau.

c) Uji flavonoid

Dibuat fase gerak kloroform-etilasetat

(8:2) dimasukkan dalam chamber, dibiarkan jenuh kemudian ditotolkan sari etil asetat dan dimasukkan dalam chamber, dielusi sampai tanda, diambil dan dibiarkan sampai kering. Ekstrak mengandung flavonoid bebas bila dilihat dibawah sinar UV $356 \quad \mathrm{~nm}$ berfluoresensi hijau/berwarna biru. 


\section{HASIL PENELITIAN}

a. Identifikasi morfologi Rosella (Hibiscus sabdariffa L.) :

Tabel 1. Hasil pemeriksaan morfologi daun Rosella (Hibiscus sabdariffa L.)

\begin{tabular}{ll}
\hline Pemeriksaan & \multicolumn{2}{c}{ Pustaka } \\
\hline & Merupakan daun tunggal, Daun bertangkai, yang \\
& daunnya bertangkai, dengan panjangnya 6-15 cm, bulat \\
& panjang daunnya $\pm 10,3 \mathrm{~cm}$, telur, bentuk lingkaran atau \\
& dengan lebarnya $\pm 10,2 \mathrm{~cm}$, oval melintang, kerapkali \\
& bentuk daun bulat telur bercangkap 3 atau berbagi 3, \\
& (orbicularis), daunnya menjari dengan kelenjar jelas pada \\
& (palminervis) dan kadang-kadang tangkai ibu tulang daun. (Van \\
& bercangkap (palmatifidus) 3, Stenis, 1995). \\
& dengan kelenjar jelas pada \\
Daun (Folium) & pangkal ibu daun, tepi daun \\
& (margo) bergerigi (serratus) \\
& dengan ujungnya (apex) \\
& meruncing (acuminatus) dan \\
& pangkal daunnya (basis) tumpul \\
& (obtusus), tulang daun berwarna \\
& merah, permukaan atas daun \\
& kasar dan berwarna hijau tua, \\
& sedangkan permukaan bawah \\
& kasar berwarna hijau muda.
\end{tabular}

\section{b. Parameter spesifik simplisia Rosella (Hibiscus sabdariffa L.) :}

Tabel 2. Hasil pemeriksaan mikroskopik serbuk daun Rosella (Hibiscus sabdariffa L.)

\begin{tabular}{ll}
\hline Pemeriksaan & \multicolumn{1}{c}{ Hasil } \\
\hline & Pada serbuk daun terdapat fragmen berupa \\
& pembuluh kayu dengan penebalan spiral dan \\
tangga, korteks berisi tanin, rambut penutup, & mesofil Ca.oksalat berbentuk pasir, serabut \\
& sklerenkim, sel minyak, epidermis dan tulang \\
& daun, stomata tipe diasitik, parenkim korteks \\
& dan kelenjar lisogen. \\
\hline
\end{tabular}

Tabel 3. Hasil pemeriksaan organoleptik serbuk daun Rosella (Hibiscus sabdariffa L.).

\begin{tabular}{ccc}
\hline No. & Pemeriksaan & Hasil \\
\hline 1. & Warna & Coklat \\
2. & Rasa & Asam \\
3. & Bau & Aromatik \\
\hline
\end{tabular}


Tabel 4. Hasil pemeriksaan reaksi identifikasi serbuk daun Rosella (Hibiscus sabdariffa L.)

\begin{tabular}{|c|c|c|c|c|c|}
\hline \multirow{2}{*}{ No. } & \multirow{2}{*}{ Uji } & \multirow{2}{*}{ Pereaksi } & \multicolumn{2}{|c|}{ Warna } & \multirow{2}{*}{ Ket } \\
\hline & & & Pustaka & Hasil & \\
\hline 1. & Lignin & Fluoroglusin $+\mathrm{HCl}$ & Merah & Merah & + \\
\hline \multirow[b]{2}{*}{2.} & \multirow{2}{*}{$\begin{array}{l}\text { Tanin } \\
\text { a. Katekol } \\
\text { b. Pirogalotanin }\end{array}$} & $\mathrm{FeCl}_{3} 1 \mathrm{~N}$ & Hijau & Hijau & + \\
\hline & & $\mathrm{NaOH}$ & Merah coklat & Coklat & - \\
\hline 3. & Dioksiantrakinon & $\mathrm{KOH} 10 \%$ & Merah & Coklat & - \\
\hline 4. & Fenol & $\mathrm{FeCl}_{3}$ & Biru-hitam & Orange & - \\
\hline 5. & Alkaloid & $\begin{array}{l}\mathrm{HCl} 0,5 \mathrm{~N}+\text { Mayer } \\
\mathrm{HCl} 0,5 \mathrm{~N}+\text { bauchardad } \\
\mathrm{HCl} 0,5 \mathrm{~N}+\text { Dragendroff }\end{array}$ & $\begin{array}{l}\text { Endapan putih } \\
\text { Endapan coklat } \\
\text { Endapan jingga }\end{array}$ & $\begin{array}{l}\text { Coklat } \\
\text { Jingga } \\
\text { Coklat }\end{array}$ & $\begin{array}{l}- \\
- \\
-\end{array}$ \\
\hline 6. & Karbohidrat & $\begin{array}{l}\text { Molish } \\
\text { Luff } \\
\text { Fehling A dan B } \\
\end{array}$ & $\begin{array}{l}\text { Cincin ungu } \\
\text { Endapan Merah } \\
\text { Endapan kuning }\end{array}$ & $\begin{array}{l}\text { Orange } \\
\text { Hijau } \\
\text { Hijau }\end{array}$ & $\begin{array}{l}- \\
- \\
-\end{array}$ \\
\hline 7. & $\begin{array}{l}\text { Aleuron } \\
\text { Pati }\end{array}$ & $\begin{array}{l}\text { lodin } 0,1 \mathrm{~N} \\
\text { Luff }\end{array}$ & $\begin{array}{l}\text { Kuning coklat- } \\
\text { coklat } \\
\text { Endapan Merah } \\
\text { bata }\end{array}$ & $\begin{array}{l}\text { Kuning coklat } \\
\text { Endapan hijau }\end{array}$ & + \\
\hline 8. & Steroid & Liberman bauchard & Biru-Hijau & Hijau-Hijau & - \\
\hline 9. & Saponin & $\mathrm{HCl} 2 \mathrm{~N}$ & Terbentuk buih & $\begin{array}{l}\text { Tidak terbentuk } \\
\text { buih }\end{array}$ & - \\
\hline 10. & Flavanoid & $\mathrm{FeCl} 3+\mathrm{HCl}$ & Merah & Merah & + \\
\hline
\end{tabular}

Keterangan : $+=$ Positif

$-\quad=$ Negatif

c. Parameter spesifik ekstrak daun Rosella (Hibiscus sabdariffa L.) :

Tabel 5. Hasil identitas ekstrak daun Rosella (Hibiscus sabdariffa L.)

\begin{tabular}{lll}
\hline No. & \multicolumn{1}{c}{ Pemeriksaan } & \multicolumn{1}{c}{ Hasil } \\
\hline 1. & Nama ekstrak & Ekstrak etanol daun Rosella (Ekstractum \\
2. & Nama lain & Hibiscus sabdariffa L. \\
3. & $\begin{array}{l}\text { Bagian tumbuhan yang } \\
\text { digunakan }\end{array}$ & Daun \\
4. & Nama Indonesia & Daun Rosella \\
\hline
\end{tabular}

Tabel 6. Hasil organoleptik ekstrak daun Rosella (Hibiscus sabdariffa L.)

\begin{tabular}{ccc}
\hline No. & Pemeriksaan & Hasil \\
\hline 1. & Bentuk & Ekstrak kering \\
2. & Warna & Hijau \\
3. & Bau & Aromatik \\
4. & Rasa & Asam \\
\hline
\end{tabular}


Tabel 7. Hasil pemeriksaan senyawa terlarut dalam air dan etanol serbuk daun Rosella (Hibiscus sabdariffa L.) :

\begin{tabular}{lccccc}
\hline No. & Pelarut & Berat sampel & Bobot sari & \% kadar & \% kadar rata-rata \\
\hline & \multirow{2}{*}{ Kloroform LP } & $5,0063 \mathrm{~g}$ & $0,3334 \mathrm{~g}$ & 6,6596 & \\
& $5,0066 \mathrm{~g}$ & $0,3284 \mathrm{~g}$ & 6,5593 & 6,6203 \\
& $5,0029 \mathrm{~g}$ & $0,3323 \mathrm{~g}$ & 6,6421 & \\
\hline \multirow{2}{*}{ 2. } & \multirow{2}{*}{ Etanol (95\%) } & $5,0001 \mathrm{~g}$ & $0,9540 \mathrm{~g}$ & 19,0796 & \multirow{2}{*}{$5,0016 \mathrm{~g}$} \\
& & $5,0016 \mathrm{~g}$ & $0,9610 \mathrm{~g}$ & 19,2138 & \\
\hline
\end{tabular}

Tabel 8. Hasil kromatografi lapis tipis ekstrak n-heksan dan etil asetat daun Rosella (Hibiscus sabdariffa L.)

\begin{tabular}{|c|c|c|c|c|c|c|c|}
\hline \multirow{2}{*}{ Fraksi } & \multirow{2}{*}{ Eluen } & \multicolumn{3}{|c|}{ Nilai Rf } & \multicolumn{3}{|c|}{ Warna noda } \\
\hline & & $254 \mathrm{~nm}$ & $366 \mathrm{~nm}$ & lod & $254 \mathrm{~nm}$ & $366 \mathrm{~nm}$ & lod \\
\hline \multirow{5}{*}{ N-heksan } & \multirow{5}{*}{$\mathrm{N}-$ Heksan : Etil asetat (3:7) } & 0,5454 & 0,7818 & 0,6363 & Hijau & Biru & Coklat \\
\hline & & 0,4545 & 0,5454 & - & Hijau & Ungu & - \\
\hline & & 0,2545 & 0,4545 & - & Hijau & Ungu & - \\
\hline & & 0,1818 & 0,2545 & - & Hijau & Biru & - \\
\hline & & - & 0,1818 & - & - & Biru & - \\
\hline \multirow{10}{*}{ Etil Asetat } & \multirow{10}{*}{$\begin{array}{l}\text { Etil asetat : methanol : Air } \\
\qquad(10: 2: 1)\end{array}$} & 0,8727 & 0,8727 & - & Hijau & Ungu & - \\
\hline & & 0,7272 & 0,7272 & - & Hijau & Biru & - \\
\hline & & 0,5636 & 0,5636 & - & Hijau & Hitam & - \\
\hline & & 0,4363 & 0,4363 & - & Hijau & Hitam & - \\
\hline & & 0,1636 & 0,3636 & - & Hijau & Biru & - \\
\hline & & - & 0,327272 & - & - & Hitam & - \\
\hline & & - & 0,2545 & - & - & Biru & - \\
\hline & & - & 0,1636 & - & - & Biru & - \\
\hline & & - & 0,1090 & - & - & Biru & - \\
\hline & & - & 0,07272 & - & - & Biru & - \\
\hline \multirow{4}{*}{ Etil Asetat } & \multirow{4}{*}{ Kloroform : Etil Asetat (8:2) } & 0,8909 & 0,8909 & - & Hijau & Ungu & - \\
\hline & & 0,7454 & 0,7454 & - & Hijau & Ungu & - \\
\hline & & - & 0,5454 & - & - & Biru & - \\
\hline & & - & 0,1272 & - & - & Biru & - \\
\hline
\end{tabular}

\section{PEMBAHASAN}

Indonesia merupakan negara didaerah tropis yang memiliki keanekaragaman tumbuhan yang dapat dimanfaatkan untuk memenuhi kebutuhan pangan dan digunakan sebagai obat. Salah satunya adalah Rosella, yang memiliki lebih dari 100 varietas, tetapi hanya ada dua varietas yang terkenal yaitu (Hibiscus sabdariffa L.) dan H. H.altissima webster. H.altissima webster biasanya dimanfaatkan untuk diambil serat batangnya, biasanya digunakan untuk membuat karung. Sedangkan (Hibiscus sabdariffa L.) digunakan sebagai obat.

Rosella (Hibiscus sabdariffa L.) adalah tumbuhan yang kasat mata daunnya mirip dengan daun dari jarak (Ricinus communis L.). Masih banyak masyarakat yang belum mengetahui khasiat dari daun Rosella dan belum diketahui secara pasti kandungan kimia yang terdapat dalam daun Rosella. Masyarakat Enrekang 
memanfaatkannya sebagai tanaman hias, hanya sebagian kecil masyarakat Enrekang yang memanfaatkan dan mengetahui khasiat daun Rosella untuk pengobatan rematik.

Berdasarkan hal tersebut, maka dilakukan identifikasi morfologi daun, untuk mengetahui bentuk morfologi dan memperoleh data parameter spesifik simplisia dan ekstrak etanol daun Rosella (Hibiscus sabdariffa L.).

Untuk pemeriksaan mofologi, diambil bagian tanaman berupa daun dengan cara diambil bagian tanaman yang masih segar, dilakukan pengamatan. Pengamatan morfologi dilakukan dengan mengamati bentuk fisik dari simplisia yakni kekhususan bentuk, warna, ukuran daun, tepi daun, ujung daun, pangkal daun dan permukaan pada daun. Berdasarkan hasil penelitian menunjukan bahwa daun Rosella (Hibiscus sabdariffa L.), merupakan daun tunggal, daunnya bertangkai, dengan panjang daunnya $\pm 10,3 \mathrm{~cm}$, dengan lebarnya $\pm 10,2$ $\mathrm{cm}$, bentuk daun bulat telur, daunnya menjari dan kadang-kadang bercangkap 3 , dengan kelenjar jelas pada pangkal ibu daun, tepi daun bergerigi, dengan ujung yang meruncing dan pangkalnya tumpul, tulang daun berwarna merah, permukaan atas daun kasar dan berwarna hijau tua, sedangkan permukaan bawah kasar berwarna hijau muda.

Parameter spesifik simplisia daun Rosella (Hibiscus sabdariffa L.) meliputi pemeriksaan organoleptik, mikroskopik dan identifikasi kandungan kimia menggunakan pereaksi tertentu.

Pemeriksaan organoleptik serbuk daun Rosella (Hibiscus sabdariffa L.) dimaksudkan untuk mengetahui sifat-sifat fisik yang khas dari daun tersebut dengan melakukan pengamatan terhadap bentuk, warna, bau dan rasa dari suatu simplisia yang merupakan pengenalan awal yang sederhana dan subjektif mungkin. Berdasarkan hasil pemeriksaan yang diperoleh maka sifat organoleptik dari serbuk daun Rosella (Hibiscus sabdariffa L.) adalah serbuk daun berwarna coklat, rasanya asam dan berbau aromatik seperti teh.

Pemeriksaan mikroskopik serbuk daun Rosella (Hibiscus sabdariffa L.) dimaksudkan untuk mengetahui fragmen-fragmen pengenal yang khas pada simplisia tersebut, sehingga memudahkan dilakukannya pemeriksaan bila simplisia telah dibuat jamu. Berdasarkan hasil pemeriksaan yang diperoleh, maka fragmen yang 
terdapat pada serbuk daun Rosella (Hibiscus sabdariffa L.) adalah pembuluh kayu dengan penebalan spiral dan tangga, korteks berisi tanin, rambut penutup, mesofil Ca.oksalat berbentuk pasir, serabut sklerenkim, sel minyak, epidermis dan tulang daun, stomata tipe diasitik, parenkim korteks dan kelenjar lisogen.

Pemeriksaan

identifikasi

kandungan kimia simplisia nabati dilakukan pada simplisia yang berupa rajangan, serbuk, ekstrak atau dalam bentuk lain yang ditambahkan dengan pereaksi tertentu dan reaksi warna dilakukan untuk pemastian identifikasi. Metode ini digunakan untuk mengetahui senyawa yang terkandung dalam serbuk daun Rosella (Hibiscus sabdariffa L.) berdasarkan hasil pemeriksaan menunjukkan bahwa senyawa yang terkandung dalam serbuk daun Rosella adalah lignin, katekol, aleuron dan flavonoid.

Parameter spesifik ekstrak daun Rosella (Hibiscus sabdariffa L.) meliputi identitas ekstrak (nama ekstrak, nama latin tumbuhan, bagian tumbuhan yang digunakan, serta nama Indonesia tumbuhan), organoleptik, senyawa terlarut dalam pelarut tertentu (kadar sari larut air dan kadar sari larut etanol) dan uji kandungan kimia ekstrak.
Pada identitas ekstrak, hasil yang diperoleh adalah nama ekstrak yaitu ekstrak etanol daun Rosella (Ekstractum ethanol sabdariffae folium), nama lain yaitu Hibiscus sabdariffa L., bagian yang digunakan yaitu daun dan nama Indonesia yaitu Rosella.

Pada pemeriksaan organoleptik ekstrak etanol daun Rosella (Hibiscus sabdariffa L.), dilakukan pemeriksaan warna ekstrak, bau, bentuk dan rasa. Dari hasil pemeriksaan yang diperoleh maka sifat organoleptik dari ekstrak etanol daun Rosella (Hibiscus sabdariffa L.) adalah ekstrak daun berwarna hijau, berbentuk ekstrak kering, mempunyai rasa yang asam dan berbau aromatik.

Penetapan senyawa terlarut dalam pelarut tertentu, dilakukan dengan tujuan agar dapat memberikan gambaran awal jumlah senyawa kandungan dengan cara melarutkan serbuk simplisia dalam pelarut organik tertentu (etanol atau air). Penetapan senyawa yang larut dalam air digunakan untuk menentukan kemampuan dari bahan obat tersebut dapat tersari dalam pelarut air dan dapat menjadi acuan penggunaan jamu dalam bentuk rebusan (infusa) oleh masyarakat, sehingga efek yang diinginkan tercapai. Penetapan 
senyawa yang larut dalam etanol digunakan untuk mengetahui apakah bahan baku obat tradisional tersebut dapat tersari dalam etanol dan dapat dijadikan dasar dalam pembuatan ekstrak. Berdasarkan penelitian yang telah dilakukan maka diperoleh hasil penetapan senyawa yang terlarut dalam pelarut tertentu terhadap serbuk daun Rosella (Hibiscus sabdariffa L.) yaitu senyawa yang larut dalam air sebesar $6,6203 \%$, dan senyawa yang larut dalam etanol sebesar 18,6992 $\%$.

Pemisahan komponen kimia yang terdapat dalam simplisia dilakukan dengan metode ekstraksi. Metode ekstraksi yang digunakan adalah maserasi karena dilihat dari struktur fisik daun Rosella (Hibiscus sabdariffa L.) itu sendiri yang lunak atau tidak keras, penyarian dilakukan dengan menggunakan cairan penyari etanol. Etanol digunakan karena etanol bersifat semi polar sehingga dapat menarik komponen senyawa polar dan non polar, selain itu etanol paling aman digunakan karena tidak bersifat toksik. Untuk memisahkan senyawa polar dan non polar digunakan pelarut non polar yaitu nheksan dan pelarut polar yaitu etil asetat dengan metode partisi cair-cair, karena larut dalam air.
Penentuan jumlah komponen kimia yang terdapat dalam ekstrak daun Rosella (Hibiscus sabdariffa L.) berupa ekstrak n-heksan dan etil asetat dilakukan dengan menggunakan metode kromatografi lapis tipis dan eluen (fase gerak) yang digunakan adalah eluen n-heksan : etil asetat $(3: 7)$, etil asetat : methanol : air (10:2:1) dan kloroform : etil asetat (8:2), dengan penampak noda yang digunakan adalah lampu UV 254 nm, $366 \mathrm{~nm}$ dan iod. Penentuan golongan senyawa dilakukan dengan pereaksi spesifik yaitu vanillin-asam sulfat untuk golongan terpenoid, dragendroff- $\mathrm{HCl}$ untuk golongan alkaloid dan antimon (III) klorida untuk golongan flavonoid.

Untuk identifikasi golongan terpenoid digunakan ekstrak n-heksan dengan eluen $\mathrm{n}$-heksan : etil asetat (3 :7), pada penampakan $254 \mathrm{~nm}$ diperoleh 4 noda, pada penampakan $366 \mathrm{~nm}$ diperoleh 5 noda dan pada saat dielusi iod diperoleh lagi 1 noda baru. Pada penyemprotan dengan vanillin-asam sulfat, kemudian dipanaskan noda berubah dari kuning menjadi lebih gelap. Hal ini menunjukkan bahwa daun Rosella positif mengandung terpenoid. Vanilinasam sulfat digunakan untuk mendeteksi senyawa atsiri (terpenoid, fenol dan turunannya serta 
fenilpropan) dengan mekanisme membentuk senyawa ikatan rangkap terkonjugasi, peristiwa ini tidak terjadi sekaligus tetapi satu persatu secara berurutan yang menyebabkan warnanya semakin lama semakin tidak stabil, dapat juga untuk mendeteksi senyawa saponin yang ditunjukkan dengan adanya bercak berwarna biru, violet biru atau terkadang berwarna kekuningn bila diamati pada sinar biasa (Moko, 2010).

Untuk identifikasi golongan alkaloid digunakan ekstrak etil asetat dengan eluen etil asetat : methanol : air (10:2:1), pada penampakan $254 \mathrm{~nm}$ diperoleh 5 noda, pada penampakan $366 \mathrm{~nm}$ diperoleh 10 noda dan pada saat dielusi iod tidak diperoleh noda baru. Pada penyemprotan dengan dragendorff awalnya tidak ada noda, kemudian dipanaskan terbentuk 3 noda yang berwarna hijau. Hal ini menunjukkan bahwa daun Rosella negatif mengandung alkaloid. Pada pembuatan pereaksi dragendorff, bismut nitrat dilarutkan $\mathrm{HCl}$ agar tidak terjadi reaksi hidrolisis karena garamgaram bismut mudah terhidrolisis membentuk ion bismutil $\left(\mathrm{BiO}^{+}\right)_{2}$. Pada uji alkaloid dengan pereaksi dragenddorff, nitrogen digunakan untuk membentuk ikatan kovalen koordinat dengan $\mathrm{K}^{+}$yang merupakan ion logam (Marliana, 2005). Reaksi positif dari uji ini adalah dengan ditunjukkan warna coklat atau jinggacoklat dan merah-jingga dengan latar belakang kuning sampai kelabu (Moko, 2010).

Untuk identifikasi golongan flavonoid digunakan ekstrak etil asetat dengan eluen kloroform : etil asetat (8 : 2), pada penampakan $254 \mathrm{~nm}$ diperoleh 2 noda, pada penampakan $366 \mathrm{~nm}$ diperoleh 4 noda dan pada saat dielusi iod tidak diperoleh noda baru. Pada penyemprotan dengan antimon (III) klorida, kemudian dilihat pada penampakan $366 \mathrm{~nm}$, noda berpendar. Hal ini menunjukkan bahwa daun Rosella positif mengandung flavonoid. Reaksi positif dari uji ini ditunjukkan dibawah sinar UV 366 nm noda akan berpendar (Sutrisno, 1993).

\section{KESIMPULAN}

Berdasarkan

hasil pemeriksaan morfologi, parameter spesifik simplisia dan ekstrak daun Rosella (Hibiscus sabdariffa L.) asal kabupaten Enrekang dapat ditarik kesimpulan sebagai berikut :

1. Pemeriksaan morfologi daun menunjukkan bahwa daun tunggal, daunnya bertangkai, dengan panjang daunnya $\pm 10,3 \mathrm{~cm}$, dengan lebarnya $\pm 10,2 \mathrm{~cm}$, 
bentuk daun bulat telur, daunnya menjari dan kadang-kadang bercangkap 3 , dengan kelenjar jelas pada pangkal ibu daun, tepi daun bergerigi, dengan ujung yang meruncing dan pangkalnya tumpul, tulang daun berwarna merah, permukaan atas daun kasar dan berwarna hijau tua, sedangkan permukaan bawah kasar berwarna hijau muda.

2. Pemeriksaan organoleptik serbuk daun Rosella, diperoleh sifat organoleptik dari serbuk daun Rosella (Hibiscus sabdariffa L.) adalah serbuk daun berwarna coklat, rasanya asam dan berbau aromatik seperti teh.

3. Pemeriksaan mikroskopik serbuk daun Rosella diperoleh fragmen spesifik berupa pembuluh kayu dengan penebalan spiral dan tangga, korteks berisi tanin, rambut penutup, mesofil, Ca.oksalat berbentuk pasir, serabut sklerenkim, sel minyak, epidermis dan tulang daun, stomata tipe diasitik, parenkim korteks dan kelenjar lisogen.

4. Identifikasi komponen kimia terhadap serbuk daun Rosella (Hibiscus sabdariffa L.) diperoleh hasil yang positif terhadap Lignin, katekol, aleuron dan flavonoid.
5. Pada identitas ekstrak, hasil yang diperoleh adalah nama ekstrak yaitu ekstrak etanol daun Rosella (Ekstractum ethanol sabdariffae folium), nama lain yaitu Hibiscus sabdariffa L., bagian yang digunakan yaitu daun dan nama Indonesia yaitu Rosella.

6. Pemeriksaan organoleptik ekstrak daun Rosella, diperoleh sifat organoleptik dari ekstrak daun Rosella (Hibiscus sabdariffa L.) adalah ekstrak daun berwarna hijau, berbentuk ekstrak kering, mempunyai rasa yang asam dan berbau aromatik.

7. Pemeriksaan senyawa larut dalam pelarut tertentu serbuk daun Rosella (Hibiscus sabdariffa L.) diperoleh senyawa yang larut dalam air 6,6203 \% dan senyawa yang larut dalam etanol $18,6992 \%$

8. Profil kromatografi lapis tipis yang disemprotkan pereaksi spesifik menunjukakan Rosella (Hibiscus sabdariffa L.) positif terpenoid dan flavonoid.

\section{DAFTAR PUSTAKA}

Backer, C.A dan R.C. bakhuizen Van Den Brink. 1963. Flora Of Java. N.V.P Noor Dhoff Groningen. The Netherlands.

Direktorat Jenderal Pengawasan Obat dan Makanan.1986. Sediaan 
Galenik.

Departemen

Kesehatan RI, Jakarta.

Direktorat Jenderal Pengawasan Obat dan Makanan.1977. Materia Medika Indonesia Jilid 1. Departemen Kesehatan RI, Jakarta.

Direktorat Jendral Pengawasan Obat dan Makanan. 1979. Farmakope Indonesia. Edisi III, Jakarta.

Direktorat Pengawasan Obat dan Makanan. 1987. Analisa Obat Tradisional. Departemen Kesehatan RI, Jakarta

Direktorat Jendral Pengawasan Obat dan Makanan. 2000. ParameterStandar Umum Ekstak Tumbuhan Obat. Departemen Kesehatan RI, Jakarta.

Hidayat T. 2007. Budi Daya Tanaman Rosela. CV. Sinar Cemerlang Abadi, Jakarta

Khopkar, S.M. 1990. Konsep Dasar Kimia Analitik. Universitas Indonesia Press, Jakarta.

Mardiah. 2010. Budi Daya dan Pengolahan Rosela. AgroMedia Pustaka, Jakarta.

Marliana Dewi. 2005. Skrining Fitokimia dan Analisis Kromatografi Lapis Tipis Komponen Kimia Buah Labu Siam (Sechium eduleJacq. Swartz.) dalam Ekstrak Etanol. (Online).

http://www.scribd.com/doc/91810 525/reaksi-saponin. Diakses 02 Mei 2012).

Maryani H dan Kristiana L. 2008. Khasiat dan Manfaat Rosela. PT AgroMedia Pustaka, Jakarta

Moko Apt, 2010, Kromatografi CairVakum Dalam Skrining Fitokimia Daun Sambiloto

(Androgaphis paniculata).

(Online),

http://moko31.wordpress.com/20

10/06/08/kromatografi-cair-

vakum-dalam-skrining-fitokimia-

daun-sambiloto-androgaphis-

paniculatal. Diakses 02 Mei 2012).

Sastrohamidjojo, Hardjono. 2007. Kromatografi. Liberty, Yogyakarta.

Stahl, Egon. 1985. Analisis Obat Secara Kromatografi dan Mikroskop. Institut Tekhnologi Bandung, Bandung.

Sudjadi, 2007. Kimia Farmasi Analisis. PT Pustaka Pelajar, Jogjakarta.

Sutrisno B. 1993. Pereaksi KLT (Kromatografi Lapis Tipis). Fakultas Farmasi Universitas Pancasila, Jakarta.

Tjitrosoepomo,G., 2005. Morfologi Tumbuhan, Cetakan kelima belas. Gajah Madah University Press, Yogyakarta.

Van Steenis. 1995. Flora. PT. Pradnya Paramita, Jakarta. 